\title{
Antioxidant and Antibacterial Activities of the Essential Oil of Moroccan Tetraclinis articulata (Vahl) Masters
}

\author{
Halima Rabib iD, ${ }^{1}$ Chaimaa Elagdi, ${ }^{2}$ Mohammed Hsaine, ${ }^{2}$ Hassan Fougrach, ${ }^{2}$ \\ Tayeb Koussa, ${ }^{1}$ and Wadi Badri ${ }^{2}$ \\ ${ }^{1}$ Laboratory of Plant Biotechnology, Ecology and Ecosystem Valorization, Department of Biology, Faculty of Sciences El Jadida, \\ Route Ben Maachou, El Jadida 24000, Morocco \\ ${ }^{2}$ Laboratory of Ecology and Environment, Department of Biology, Faculty of Sciences Ben M'sik, \\ P.B. Av Driss El Harti Sidi Othman, Casablanca 7955, Morocco
}

Correspondence should be addressed to Halima Rabib; rabib.halima23@gmail.com

Received 10 January 2020; Revised 16 April 2020; Accepted 5 June 2020; Published 25 June 2020

Academic Editor: Robert J. Linhardt

Copyright (C) 2020 Halima Rabib et al. This is an open access article distributed under the Creative Commons Attribution License, which permits unrestricted use, distribution, and reproduction in any medium, provided the original work is properly cited.

The purpose of this study is to evaluate and compare the antioxidant and antibacterial activities of essential oil isolated from Tetraclinis articulata (Vahl) leaves, Masters originating in Morocco (Benslimane Region, Atlantic-influenced plain). The analysis of the major compounds of essential oil was performed by gas chromatography and mass spectrometry, and this oil is dominated by bornyl acetate $(35.05 \%)$, camphor $(11.17 \%)$, and $\alpha$-pinene $(10.84 \%)$. The antioxidant properties were evaluated by the test of the radical trap 2,2-diphényl-1-picrylhydrazyl (DPPH), and the antimicrobial activity of T. articulata essential oil was tested against clinical isolates of Staphylococcus aureus, Pseudomonas aeruginosa, and Escherichia coli which have been inhibited from the $25 \mu \mathrm{g} / \mathrm{mL}$.

\section{Introduction}

As part of our work on the essential oils of Tetraclinis articulata [1], this plant is a very slow-growing coniferous species, longevity of which may exceed 400 years. In height, the annual increment is estimated to be $20 \mathrm{~cm} /$ year up to 25 years and 10 $\mathrm{cm} /$ year up to 60 years. In diameter, it is 3 to $4 \mathrm{~mm} /$ year up to 30 years and 1.5 to $2.5 \mathrm{~mm} /$ year up to 60 years. These numbers depend on several parameters, including soil depth and annual precipitation [2].

It is characterized by a clear crown and an irregular pyramid port, and its foliage is persistent; the leaves appear vertically by four, long welded to the stem. The twigs, green, flattened, and covered with articulated leaves, hence the name $T$. articulata [3].

The majority of the Tetraclinaie area of Morocco is located in the semiarid bioclimatic floor with a moderate, gentle, fiery variant. They can also grow in the subhumid with a warm, mild, or temperate variant on filterable soils, on dense slopes or on hot lights [4]. It has always been used in folk medicine due to its varied therapeutic effects; it is more used against intestinal and respiratory infections also against skin infections $[5,6]$.

The use of synthetic antioxidant molecules is currently being questioned due to potential toxicological risks. New plant sources of natural antioxidants are now being sought $[7,8]$. Indeed, the polyphenols are natural compounds that are widespread in the plant reign, which are of increasing importance through their health benefits [9]. Their role as natural antioxidants is gaining interest in cancer prevention and treatment and inflammatory and cardiovascular diseases [10].

The antimicrobial properties of essential oils have been known and used for a long time, but this use was based on traditional practices [11] and applications without precise scientific bases. These days, they are used on scientific and rational grounds, since many research studies are conducted on the antimicrobial properties of EOs in aromatic plants [12-15].

In the literature, studies on the biological activities of T. articulata oils have shown that these species are antibacterial, antifungal, and cytotoxic [16-19].

This work is part of the research and development of bioactive substances such as natural substances with 
antioxidant activity of interest in biopharmacology. The main objective of this work is to assess in vitro the essential oil antioxidant activity of the aerial part of Tetraclinis articulata (Vahl) using the method of DPPH free radical trapping and the antibacterial activity on three strains: Staphylococcus aureus, Pseudomonas aeruginosa, and Escherichia coli.

\section{Materials and Methods}

2.1. Plant Material. The leaves of T. articulata were collected from Benslimane Region precisely in Ain Dakhla Atlanticinfluenced plain (N 33 40.688 W 7 00.494, altitude: 207 m), and this region has a mediterranean climate and a limestone soil. The harvest was carried out on trees taken at random in January 2018. The identification of the plant was made in our laboratory. The samples were then dried in air at room temperature $\left(25^{\circ} \mathrm{C}\right)$ and were protected from light for nine days.

2.2. Extraction of Essential Oil. Extraction of the essential oil from the aerial part of the tree was carried out by steaming with a Clevenger-type apparatus [20], in a 5-liter balloon containing 2 liters of distilled water. The extractions were repeated three times in order to recover considerable volumes. The essential oil obtained has been stored in small, opaque bottles and placed in a refrigerator at $4^{\circ} \mathrm{C}$ until used for testing antioxidant and antibacterial activities.

2.3. GC/MS Analysis. Three chromatographic analyses were performed, and the essential oil was analyzed on a HewlettPackard Gas Chromatograph Model 5890 coupled to a Hewlett-Packard Model 5971, equipped with a DB5 MS column $(30 \mathrm{~m} \times 0.25 \mathrm{~mm} ; 0.25 \mu \mathrm{m})$, programming from $50^{\circ} \mathrm{C}(5 \mathrm{~min})$ to $300^{\circ} \mathrm{C}$ at $5^{\circ} \mathrm{C} / \mathrm{min}$, with a 5 -min hold. The helium was used as the carrier gas $(1.0 \mathrm{~mL} / \mathrm{min})$; injection was in split mode (1:30); injector and detector temperatures were $250^{\circ} \mathrm{C}$ and $280^{\circ} \mathrm{C}$, respectively. The mass spectrometer worked in EI mode at $70 \mathrm{eV}$, electron multiplier at $2500 \mathrm{~V}$, and ion source temperature at $180^{\circ} \mathrm{C}$; MS data were acquired in the scan mode in the $\mathrm{m} / z$ range $33-450$.

The majority constituents of essential oil were identified in comparison with their specters of mass with those of the NIST mass spectral library.

2.4. Antioxidant Activity. The antioxidant activity of a compound corresponds to its ability to resist oxidation. Indeed, most synthetic or natural antioxidants have the hydroxyphenolic group in their structures and the antioxidant properties are attributed in part, to the ability of these natural compounds to trap free radicals such as hydroxyl radicals $\left(\mathrm{OH}^{\bullet}\right)$ and superoxides $\left(\mathrm{O}_{2}^{*}\right)$ [21].

The measurement of antiradical activity was tested using the Blois method [22] as described by Brand-Williams et al. [23] with some modifications. The principle of this method is based on the measurement of DPPH (2,2-diphenyl-1-picrylhydrazyl) free radical scavenging in solution in methanol according to the reaction in Figure 1. The spectrophotometer measurements are made at $517 \mathrm{~nm}$. It, therefore, provides a practical means of measuring the antioxidant activity of essential oils.

Thus, from a standard oil solution of $2 \mathrm{mg} / \mathrm{mL}$, daughter (diluted) solutions were prepared by successive dilution in methanol. Then, at each concentration, a volume of a methanol solution of DPPH was added. The reaction mixture was incubated in the dark at room temperature for 30 minutes. The vitamin $\mathrm{C}$ and butylhydroxytoluene (BHT) were prepared in the same condition and then used as a standard.

At the end of the incubation period, the absorbance at $517 \mathrm{~nm}$ is read and the antioxidant activity is calculated according to the following equation:

$$
\% \mathrm{IP}=\left\{\frac{(\text { Abs control }- \text { Abs sample })}{(\text { Abs control })}\right\} \times 100,
$$

where \%IP is the percentage of inhibition and Abs is the absorbance at $517 \mathrm{~nm}$.

2.5. Antibacterial Activity. The aromatogram was made on Petri dishes filled with Muller-Hinton agar. The agar is inoculated with $100 \mu \mathrm{L}$ of suspensions of $10^{8} \mathrm{cfu} / \mathrm{mL}$ and then deposited on its surface of Whatman paper discs $(6 \mathrm{~mm})$ impregnated with $10 \mu \mathrm{L}$ of the essential oil. In order for the essential oil to diffuse, Petri dishes are then closed and left at room temperature for $30 \mathrm{~min}$, then incubated at $37^{\circ} \mathrm{C}$ for $24 \mathrm{~h}$.

Once incubation is complete, the interpretation of the results is performed by measuring the inhibition zones [24].

The minimum inhibitory concentration (MIC) was evaluated according to published procedures $[25,26]$; these concentrations were determined by the CLSI microdilution method (2006) on 96-well round bottomed microplates with some modifications. For a concentration of $10^{5} \mathrm{cfu} / \mathrm{mL}$, $10^{8} \mathrm{cfu} / \mathrm{mL}$ bacterial suspensions were diluted 1/1000 with the same culture medium (TS).

Essential oil has been diluted by Tween 80 to $1 \%$ to have a concentration of $500 \mathrm{mg} / \mathrm{mL}$, and then the first 10 columns of the microplate are filled by the different concentrations of essential oil; from this solution, a series of $1 / 2$ fold dilutions were prepared to obtain a concentration range between 500 and $1 \mathrm{mg} / \mathrm{mL}$. On microplates, the negative control (column $\mathrm{N}^{\circ} 11$ ) was chosen to fill the wells with $100 \mu \mathrm{L}$ sterile broth. Positive control wells (column $\mathrm{N}^{\circ} 12$ ) were filled with $100 \mu \mathrm{L}$ of the standardized microbial suspension at $10^{5} \mathrm{cfu} / \mathrm{mL}$. Then, the plates were incubated at $37^{\circ} \mathrm{C}$ for 24 hours [1].

\section{Results and Discussion}

3.1. The Majority Component of Essential Oil. The average yield of essential oil extracted from the leaves of T. articulata (Vahl) is $0.5 \%$. This oil, pale yellow, has a strong balsamic smell.

The essential oil contents of the fresh and dry leaves of Tetraclinis articulata from different Moroccan stations vary from 0.06 to $0.81 \%$ and are, therefore, very close to our value $[17,27-30]$. 


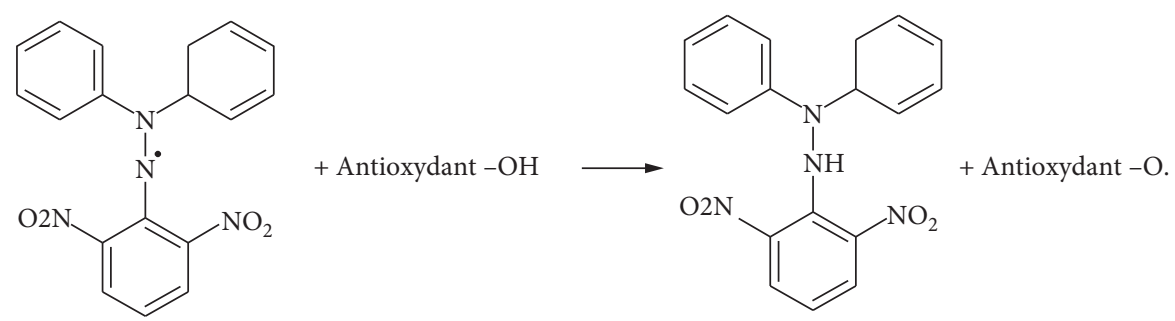

FIgURE 1: The reaction of an antioxidant with the radical DPPH.

The GC/MS analysis of essential oil identified seven majority constituents (Figure 2).

Our essential oil is rich in monoterpenic hydrocarbons (35.18\%) and esters (35.05\%); the following table represents the majority components with their percentage (Table 1).

The results of the chromatographic analysis show that this essential oil is very rich in monoterpenic hydrocarbons and the bornyl acetate (35.05\%), and camphor (11.17\%) and $\alpha$-pinene $(10.84 \%)$ are the clear majority compounds. A study by Bourkhiss et al. showed that essential oil from Essaouira is rich in camphor (31.6\%) and the bornyl acetate (25.4\%) [31].

Two compositions have been identified in the Khemisset region, and the majority compound of this oil is bornyl acetate (30.7\% and $30.6 \%$, respectively) followed by $\alpha$-pinene (23.5\% and $16.8 \%$, respectively) and limonene $(23.31 \%$ and $5.7 \%$, respectively). Camphor is also present at significant levels $(17.3 \%$ and $18.6 \%$, respectively) $[16,32,33]$.

Also, the essential oils of the dry and fresh leaves of $T$. articulata harvested during the month of December in the region of Marrakech are predominantly by $\alpha$-pinene $(23.0 \%$; $41.0 \%)$ and bornyl acetate (36.4\%; 20.6\%) [34].

In addition, in another sample taken in January in the same region, the authors determined bornyl acetate (26.8\%) and camphor (22.4\%) as the majority compounds, followed by $\alpha$-pinene (7.2\%) and borneol (6.4\%) [35].

Another study examined the alteration of the majority compounds of essential oils extracted from Barbary thuja leaves from Morocco during shade drying. The majority of compounds are bornyl acetate (30.6\%), camphor (18.6\%), $\alpha$-pinene (16.8\%), limonene (5.7\%), and borneol (4.7\%). The additional concentration of these five major components increased from $61.1 \%$ on the first day to $65.3 \%$ on the thirteenth day of shade drying. They also note irregular changes during the drying period. For example, $\alpha$-pinene varies from $23.54 \%$ on the first day to $28.78 \%$ on the thirteenth day, while bornyl acetate progresses from $30.74 \%$ to $22.27 \%$ during the same period. The other components remain practically stable during the storage period [29].

As indicated in the literature, these three compounds are the most abundant in the essential oil of the Barbary thuja collected in different regions in Morocco, and the limonene (7.12\%), borneol (9.79\%), camphene (3.14\%), and $\alpha$-thujone $(2.51 \%)$ are present in significant quantities [27-30]. On the other hand, the majority components of our last work on Tetraclinis articulata from Ras Elma Tazakka (mountain, latitude: $34^{\circ} 03^{\prime} 03^{\prime \prime}$; longitude: W $04^{\circ} 10^{\prime} 07^{\prime \prime}$; altitude: $1496 \mathrm{~m}$. The climate was subhumid) and Debdou regions (plain,

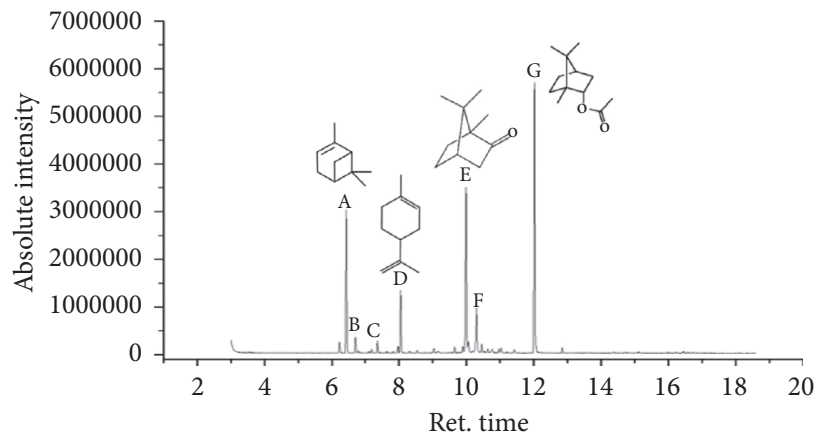

Figure 2: Chromatogram of the major components of Tetraclinis articulata essential oil ((A) $\alpha$-pinene, (B) camphene, (C) $\alpha$-thujone, (D) limonene, (E) camphor, (F) borneol, and (G) bornyl acetate).

TABLE 1: Majority essential oil compounds of the aerial part of Tetraclinis articulata (Vahl) Masters.

\begin{tabular}{lc}
\hline The majority constituents & Percentage (\%) \\
\hline A: $\alpha$-pinene & 10.84 \\
B: camphene & 3.14 \\
C: $\alpha$-thujone & 2.51 \\
D: limonene & 7.12 \\
E: camphor & 11.17 \\
F: borneol & 6.79 \\
J: bornyl acetate & 35.05 \\
\hline
\end{tabular}

latitude: $34^{\circ} 03^{\prime} 15^{\prime \prime}$; longitude: W $02^{\circ} 59^{\prime} 15^{\prime \prime}$; altitude: $765 \mathrm{~m}$. The climate was semihumid) showed that the majority components are the bornyl acetate $(34.84 \% ; 32.55 \%)$, $\alpha$-pinene $(11.41 \% ; 18.83 \%)$, camphor $(11.24 \% ; 11.31 \%)$, and limonene $(11.94 \% ; 8 \%)$ [1].

The quantitative difference in the majority compounds can be explained by the adaptation of the abiotic factors, such as the climate specific to the regions from which the samples come, and geographical factors, such as altitude and soil nature, which orient biosynthesis towards the preferential formation of specific products [36, 37].

3.2. Antioxidant Activity. The results of the antioxidant activity of the Barbary thuja essential oil are reported in Figure 3.

We found that the essential oils of the aerial part of Tetraclinis articulata have a very low antioxidant activity compared with standard antioxidants at a concentration of $2 \mathrm{mg} / \mathrm{mL}$. 


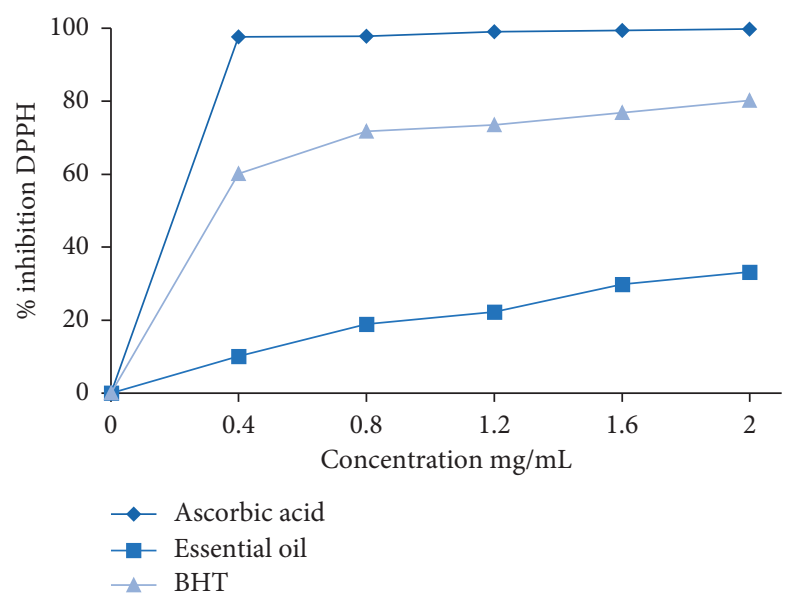

Figure 3: Percentage inhibition curve as a function of the concentration.

According to the literature, the antioxidant activity of Tetraclinis articulata has been studied by several authors. The majority of this work confirms our results.

Ben Jemia et al. [38] studied the antioxidant activity of the essential oil of Thuja leaves from Tunisia. The results of the DPPH test showed a low activity, with an $\mathrm{IC}_{50}$ of the order of $25.50 \pm 0.57 \mu \mathrm{g} / \mathrm{mL}$, two times less important than that of the positive control (BHT) $\left(\mathrm{IC}_{50}=12.0 \pm 0.13 \mu \mathrm{g} / \mathrm{mL}\right)$. It should be noted that bornyl acetate (31.4\%), $\alpha$-pinene $(24.5 \%)$, and camphor $(20.3 \%)$ are the majority constituents of this essential oil.

Also, El Jemli et al. [35] studied the antioxidant power of the essential oils of the Thuja leaves collected in the Marrakech region, and the majority of which are bornyl acetate $(26.8 \%)$ and camphor (22.4\%), followed by the $\alpha$-pinene (7.2\%) and borneol (6.4\%). These essential oils have low antioxidant activity, with an $\mathrm{IC}_{50}$ obtained by the DPPH test, the order of $12.05 \times 103 \pm 0.24 \mu \mathrm{g} / \mathrm{mL}$, significantly lower than the standard $\left(\mathrm{IC}_{50}=4.20 \pm 0.02 \mu \mathrm{g} / \mathrm{mL}\right)$.

On the other hand, the essential oil obtained by hydrodistillation, very low in phenolic compound ( $8.89 \mathrm{mg}$ EAG/g), has the lowest antioxidant activity, with an $\mathrm{IC}_{50}$ value of $3681.49 \pm 69.33 \mu \mathrm{g} / \mathrm{mL}$. Polyphenols are known to have a high capacity to entrapment free radicals from the presence of hydroxyl substituents in their aromatic structure [39].

Similarly, the essential oils of leaves, rich in total phenols (320.54 mg EAG/g EO), showed significant antioxidant potential, higher than that of the reference compound butylhydroxytoluene (BHT). The percentage of inhibition obtained by the DPPH test is in the order of $89.3 \%$ compared to $50.3 \%$ [33].

3.3. Antibacterial Activity. The efficiency of essential oil on sensitive microbial strains was determined by the measurement of the minimum inhibitory concentrations (MICs).

The results of the antibacterial activity are given in Table 2.

Teixeira et al. argued that any essential oil with MICs below $2000 \mu \mathrm{g} / \mathrm{mL}$ is considered to have an antimicrobial potential [40].
TABLe 2: Antibacterial activity in the essential oil of T. articulata leaves (Vahl).

\begin{tabular}{lcc}
\hline & & E.O \\
Staphylococcus aureus ATCC29213 & $\varnothing$ & $48 \pm 00$ \\
& MIC & $1.56 \pm 0.00$ \\
& MBC & $1.56 \pm 0.00$ \\
\hline \multirow{3}{*}{ Escherichia coli ATCC25922 } & $\varnothing$ & $8 \pm 00$ \\
& MIC & $25 \pm 0.00$ \\
& MBC & $25 \pm 0.00$ \\
\hline & $\varnothing$ & $30 \pm 00$ \\
Pseudomonas aeruginosa ATCC27853 & MIC & $6.25 \pm 0.00$ \\
& MBC & $6.25 \pm 0.00$ \\
\hline
\end{tabular}

MBC: minimum bactericidal concentration; MIC: minimum inhibitory concentration; Ø: zones of inhibition.

The results show that the MIC values agree in general with those of the diameters of inhibition, and the essential oils which have induced a large zone of inhibition have the smallest MICs on the strains corresponding.

This is the case with our essential oil, which has proved to be particularly important and effective against Staphylococcus aureus, with a very low MIC equal to $1.56 \mu \mathrm{g} / \mathrm{mL}$, and also for Pseudomonas aeruginosa $(6.25 \mu \mathrm{g} / \mathrm{mL})$.

Our results are consistent with those of Lemos et al. [41], who argue that the essential oils of Rosmarinus officinalis, which contain between 24.4 and $35.9 \%$ of camphor, show significant activity against $S$. aureus with MICs ranging from 0.5 to $2.0 \mu \mathrm{L} / \mathrm{mL}$.

In addition, the antimicrobial activity of bornyl acetate and camphor has been demonstrated by several works. Indeed, Bougatsos et al. [42], Vagionas et al. [43], and Runyoro et al. [44] report MICs ranging from 1.75 to $4.88 \mathrm{mg} / \mathrm{mL}$ for bornyl acetate against several microbial strains. On the other hand, esters and especially bornyl acetate (30.74\%) also contribute to the antibacterial effect. Based on the work of Tzakou et al. [45], the essential oils of two chemotypes of Thymus longicaulis rich in geranyl acetate for the first and in acetate $\alpha$-terpenyl for the second possess a high antimicrobial activity.

We also found that Staphylococcus aureus was the most sensitive to the essential oil. Indeed, most studies report that bacteria in Gram $(+)$ are generally more sensitive than in Gram (-) [46, 47].

Thus, although the antimicrobial activity of essential oil is attributed mainly to its majority compound, the synergistic or antagonistic effect of each of its constituents present in low content is also considered [46, 48,49].

We can conclude that studies of medicinal plants show a variability in the composition of essential oils that influences the potential of biological activities. This variation was most often correlated with the difference in regions, the harvest period [50-53], environmental and agronomic conditions [54], and the extraction method [55].

\section{Conclusion}

The chemical composition of essential oil leaves harvested from the Benslimane region showed that the majority components are bornyl acetate (35.05\%), camphor (11.17\%), 
and $\alpha$-pinene (10.84\%). Tetraclinis articulata essential oil is very active on bacterial strains, especially Staphylococcus aureus, with inhibition zones ranging from 48 to $30 \mathrm{~mm}$ diameters. Contrary to the results obtained by the DPPH method, low antioxidant power was found for the essential oil tested compared to the reference compounds.

We can conclude that studies of medicinal plants show variability in the composition of essential oils that affects the potential of biological activities. This variation was most often correlated with the difference in the regions, the harvest period, and environmental conditions.

\section{Data Availability}

The data used to support the findings of this study are included within the article.

\section{Conflicts of Interest}

The authors declare that they have no conflicts of interest.

\section{References}

[1] H. Rabib, S. Zougagh, M. Hsain, W. Badri, and T. Koussa, "GC/MS analysis and antibacterial activity of the essential oil of Moroccan Tetraclinis articulata (vahl) Masters," Mediterranean Journal of Chemistry, vol. 8, no. 4, pp. 302-307, 2019.

[2] M. EL Mouridi, T. Laurent, A. Famiri et al., "Caractérisation physique du bois de la loupe de thuya (Tetraclinis articulata (vahl) masters)," Physical Chemical News, vol. 59, pp. 57-64, 2011.

[3] K. Toudert-Taleb, M. Hedjal-Chebheb, H. Hami et al., "Composition of essential oils extracted from six aromatic plants of Kabylian origin (Algeria) and evaluation of their bioactivity on Callosobruchus maculatus (fabricius, 1775) (coleoptera: bruchidae)," African Entomology, vol. 22, no. 2, pp. 417-427, 2014.

[4] M. Fennane, "Etude phytoécologique des tétraclinaies marocaines," Revue des Composites et des Matériaux Avancés, vol. 19, no. 3, pp. 261-279, 1987.

[5] J. Buhagiar, M. T. C. Podestà, P. L. Cioni, G. Flamini, and I. Morelli, "Essential oil composition of different parts of Tetraclinis articulata," Journal of Essential Oil Research, vol. 12, no. 1, pp. 29-32, 2000.

[6] E. Le Floc'h, Contribution to Ethnobotanical Study of the Flora of Tunisia. Program Flora and Vegetation in Tunisia, pp. 36-37, Tunisian Scientific Publications, Tunisia, 1983.

[7] M. Suhaj, "Spice antioxidants isolation and their antiradical activity: a review," Journal of Food Composition and Analysis, vol. 19, no. 6-7, pp. 531-537, 2006.

[8] M. B. Tadhani, V. H. Patel, and R. Subhash, "In vitro antioxidant activities of Stevia rebaudiana leaves and callus," Journal of Food Composition and Analysis, vol. 20, no. 3-4, pp. 323-329, 2007.

[9] C. Koechlin-Ramonatxo, "Oxygène, stress oxydant et supplémentations antioxydantes ou un aspect différent de la nutrition dans les maladies respiratoires," Nutrition Clinique et Métabolisme, vol. 20, no. 4, pp. 165-177, 2006.

[10] D. I. Vârban, M. Duda, R. Vârban et al., "Research concerning the organic technology for Satureja hortensis L. culture," Bulletin UASVM Agriculture, vol. 66, no. 2, pp. 225-229, 2009.

[11] G. M. Hala, H. Christ, and K. Carla, "Traditional uses of Salvia libanotica (East Mediterranean sage) and the effects of essential oils," Journal of Ethnopharmacology, vol. 71, no. 3, pp. 513-520, 2000.

[12] G. Flamini, P. L. Cioni, R. Puleio, I. Morelli, and L. Panizzi, "Antimicrobial activity of the essential oil of Calamintha nepeta and its constituent pulegone against bacteria and fungi," Phytotherapy Research, vol. 13, no. 4, pp. 349-351, 1999.

[13] M. Marino, C. Bersani, and G. Comi, "Antimicrobial activity of the essential oils of Thymus vulgaris L. measured using a bioimpedometric method," Journal of Food Protection, vol. 62, no. 9, pp. 1017-1023, 1999.

[14] SD. Cox, CM. Mann, JL. Markham et al., "The mode of antimicrobial action of the essential oil of Melaleuca alternifolia (tea tree oil)," Journal Applied Microbiology, vol. 88, pp. 170-175, 2000.

[15] H. J. D. Dorman and S. G. Deans, "Antimicrobial agents from plants: antibacterial activity of plant volatile oils," Journal of Applied Microbiology, vol. 88, no. 2, pp. 308-316, 2000.

[16] M. Bourkhiss, M. Hnach, B. Bourkhiss et al., "Composition chimique et propriétés antimicrobiennes de l'huile essentielle extraite des feuilles de Tetraclinis articulata (Vahl) du Maroc," Afrique Science, vol. 3, pp. 232-242, 2007.

[17] B. Bourkhis, M. Ouhssine, M. Hnach et al., "Composition chimique et bioactivité de l'huile essentielle des rameaux de Tetraclinis articulata," Bulletin de la Société de Pharmacie de Bordeaux, vol. 146, pp. 75-84, 2007.

[18] M. Bourkhis, M. Hnach, T. Lakhlifi et al., "Production et caractérisation de l'huile essentielle de la sciure de bois de Tetraclinis articulata (Vahl) masters" Bulletin de la Société Royale des Sciences de Liège, vol. 79, pp. 4-11, 2010.

[19] J. A. Buhagiar, M. T. Podesta, A. P. Wilson et al., "The induction of apoptosis in human melanoma, breast and ovarian cancer cell lines using an essential oil extract from the conifer Tetraclinis articulata," Anticancer Research, vol. 19, pp. 5435-5443, 1999.

[20] B. Meyer-Warnod, "Natural essential oils: extraction processes and applications to some major oils," Perfumer \& Flavoris, vol. 9, pp. 93-103, 1984.

[21] R. P. Adams, Identification of Essential Oil Components by Gaz Chromatography/Quadrupole MassSpectroscopy, Allured Publishing, Carol Stream, IL, USA, 2001.

[22] M. S. Blois, "Antioxidant determinations by the use of a stable free radical," Nature, vol. 181, no. 4617, pp. 1199-1200, 1958.

[23] W. Brand-Williams, M. E. Cuvelier, and C. Berset, "Use of a free radical method to evaluate antioxidant activity," LWT Food Science and Technology, vol. 28, no. 1, pp. 25-30, 1995.

[24] A. G. Ponce, R. Fritz, C. Del Valle, and S. I. Roura, "Antimicrobial activity of essential oils on the native microflora of organic Swiss Chard," LWT-Food Science and Technology, vol. 36, no. 7, pp. 679-684, 2003.

[25] K. Güven, S. Çelik, and İ. Uysal, "Antimicrobial activity of centaurea. Species," Pharmaceutical Biology, vol. 43, no. 1, pp. 67-71, 2005.

[26] F. Demirci, K. Guven, B. Demirci, M. Y. Dadandi, and K. H. C. Baser, "Antibacterial activity of two phlomis essential oils against food pathogens," Food Control, vol. 19, no. 12, pp. 1159-1164, 2008.

[27] A. F. Barrero, M. M. Herrador, P. Arteaga et al., "Chemical composition of the essential oils of leaves and wood of Tetraclinis articulata (vahl) masters," Journal of Essential Oil Research, vol. 17, no. 2, pp. 166-168, 2005.

[28] M. Bourkhiss, M. Hnach, B. Bourkhiss et al., "Chemical composition and antimicrobial properties of the essential oil 
extracted from the leaves of Tetraclinis articulata (vahl) from Morocco," Afrique Science, vol. 3, pp. 232-242, 2007.

[29] M. Bourkhiss, M. Hanach, B. Bourkhiss et al., "Effet de séchage sur la teneur et la composition chimique des huiles essentielles de Tetraclinis articulata (Vahl) masters," Agro Solutions, vol. 20, no. 1, pp. 44-48, 2009.

[30] N. Achak, A. Romane, M. Alifriqui, and R. P. Adams, "Chemical studies of leaf essential oils of three species of Juniperus from tensift $\mathrm{Al}$ haouz-Marrakech region (Morocco)," Journal of Essential Oil Research, vol. 21, no. 4, pp. 337-341, 2009.

[31] B. Bourkhiss, M. Ouhssine, M. Hnach et al., "Composition chimique de l'huile essentielle de Tetraclinis articulata (vahl) du Maroc," Physical \& Chemical News, vol. 35, pp. 128-132, 2007.

[32] M. Bourkhiss, M. Hnach, J. Paolini et al., "Composition chimique des huiles essentielles de la sciure de bois et de feuilles de Tetraclinis articulata (vahl) masters du Maroc," Bulletin de la Société Royale des Sciences de Liège, vol. 78, pp. 281-289, 2009.

[33] M. Bourkhiss, M. Hnach, J. Paolini et al., "Propriétés antioxydantes et anti-inflammatoires des huiles essentielles des différentes parties de Tetraclinis articulata (vahl) masters du maroc," Bulletin de la Société Royale des Sciences de Liège, vol. 79, pp. 141-154, 2010.

[34] N. Achak, A. Romane, M. Alifriqui, and M. Markouk, "Chemical composition, organic and mineral contents of leaves of Tetraclinis articulata (vahl) masters from the tensiftAl haouz, Marrakech region (Morocco)," Journal of Essential Oil Bearing Plants, vol. 12, no. 2, pp. 198-204, 2009.

[35] M. El Jemli, R. Kamal, I. Marmouzi et al., "Chemical composition, acute toxicity, antioxidant and anti-inflammatory activities of Moroccan Tetraclinis articulata L." Journal of Traditional and Complementary Medicine, vol. 7, no. 3, pp. 281-287, 2016.

[36] M. Brada, M. Bezzina, M. Marlier et al., "Variabilite de la composition chimique des huiles essentielles de Mentha rotundifolia du nord de l'Algerie," Biotechnology, Agronomy, Society and Environment, vol. 11, no. 1, pp. 3-7, 2007.

[37] M. Ghanmi, B. Satrani, A. Chaouch et al., "Composition chimique et activité antimicrobienne de l'essence de térébenthine du pin maritime (Pinus pinaster) et du pin d'alep (Pinus halepensis) du Maroc," Acta Botanica Gallica, vol. 154, no. 2, pp. 293-300, 2007.

[38] M. Ben Jemia, S. Chaabane, F. Senatore et al., "Studies on the antioxidant activity of the essential oil and extract of Tunisian Tetraclinis articulata (vahl) mast. (Cupressaceae)," Natural Product Research, vol. 27, pp. 1419-1430, 2012.

[39] D. Villaño, M. S. Fernández-Pachón, M. L. Moyá, A. M. Troncoso, and M. C. García-Parrilla, "Radical scavenging ability of polyphenolic compounds towards DPPH free radical," Talanta, vol. 71, no. 1, pp. 230-235, 2007.

[40] M. C. Teixeira Duarte, G. Mara Figueira, A. Sartoratto et al., "Anticandida activity of Brazilian medecinal plants," Journal of Ethnopharmacology, vol. 97, no. 9, pp. 305-311, 2005.

[41] M. F. Lemos, M. F. Lemos, H. P. Pacheco, D. C. Endringer, and R. Scherer, "Seasonality modifies rosemary's composition and biological activity," Industrial Crops and Products, vol. 70, pp. 41-47, 2015.

[42] C. Bougatsos, O. Ngassapa, D. K. B. Runyoro, and I. B. Chinou, "Chemical composition and in vitro antimicrobial activity of the essential oils of two Helichrysum species from Tanzania," Zeitschrift für Naturforschung C, vol. 59, no. 5-6, pp. 368-372, 2004.
[43] K. Vagionas, K. Graikou, O. Ngassapa, D. Runyoro, and I. Chinou, "Composition and antimicrobial activity of the essential oils of three satureja species growing in Tanzania," Food Chemistry, vol. 103, no. 2, pp. 319-324, 2007.

[44] D. Runyoro, O. Ngassapa, K. Vagionas, N. Aligiannis, K. Graikou, and I. Chinou, "Chemical composition and antimicrobial activity of the essential oils of four ocimum species growing in Tanzania," Food Chemistry, vol. 119, no. 1, pp. 311-316, 2010.

[45] O. Tzakou, E. Verykokidou, V. Roussis, and I. Chinou, "Chemical composition and antibacterial properties of Thymus longicaulis subsp. chaoubardii oils: three chemotypes in the same population," Journal of Essential Oil Research, vol. 10, no. 1, pp. 97-99, 1998.

[46] S. Burt, "Essential oils: their antibacterial properties and potential applications in foods-a review," International Journal of Food Microbiology, vol. 94, no. 3, pp. 223-253, 2004.

[47] F. Deba, T. D. Xuan, M. Yasuda, and S. Tawata, "Chemical composition and antioxidant, antibacterial and antifungal activities of the essential oils from Bidens pilosa Linn. var. radiata," Food Control, vol. 19, no. 4, pp. 346-352, 2008.

[48] S.-T. Chang, P.-F. Chen, and S.-C. Chang, "Antibacterial activity of leaf essential oils and their constituents from Cinnamomum osmophloeum," Journal of Ethnopharmacology, vol. 77, no. 1, pp. 123-127, 2001.

[49] D. J. Daferera, B. N. Ziogas, and M. G. Polissiou, "The effectiveness of plant essential oils on the growth of Botrytis cinerea, Fusarium sp. and Clavibacter michiganensis subsp. michiganensis," Crop Protection, vol. 22, no. 1, pp. 39-44, 2003.

[50] J.-C. Chalchat, R.-P. Garry, A. Michet, B. Benjilali, and J. L. Chabart, "Essential oils of rosemary (Rosmarinus officinalis L.). The chemical composition of oils of various origins (Morocco, Spain, France)," Journal of Essential Oil Research, vol. 5, no. 6, pp. 613-618, 1993.

[51] YO. Celiktas, G. Girgin, H. Orhan et al., "Screening of free radical scavenging capacity and antioxidant activities of Rosmarinus officinalis extracts with focus on location and harvesting times," European Food Research and Technology, vol. 224, pp. 443-445, 2007.

[52] O. Y. Celiktas, E. E. H. Kocabas, E. Bedir, F. V. Sukan, T. Ozek, and K. H. C. Baser, "Antimicrobial activities of methanol extracts and essential oils of Rosmarinus officinalis, depending on location and seasonal variations," Food Chemistry, vol. 100, no. 2, pp. 553-559, 2007.

[53] R. Jamshidi, Z. Afzali, and D. Afzali, "Chemical composition of hydrodistillation essential oil of rosemary in different origins in Iran and comparison with other countries," American- Eurasian Journal of Agricultural \& Environmental Sciences, vol. 5, no. 1, pp. 78-81, 2009.

[54] M. Moghtader and D. Afzali, "Study of the antimicrobial proprieties of the oil of Rosemary" American-Eurasian Journal of Agricultural \& Environmental Sciences, vol. 5, no. 3, pp. 393-397, 2009.

[55] P. López, C. Sánchez, R. Batlle, and C. Nerín, "Solid- and vapor-phase Antimicrobial activities of six essential oils: susceptibility of selected foodborne bacterial and fungal strains," Journal of Agricultural and Food Chemistry, vol. 53, no. 17, pp. 6939-6946, 2005. 